\title{
Community empowerment for managing wild boar: a longitudinal case study of northern Italy 2001-2018
}

\author{
Stefano Giacomelli $^{1}$, Michael Gibbert $^{2}$ and Roberto Viganò ${ }^{3}$
}

\begin{abstract}
We studied the issue of wild boar (Sus scrofa) management over 17 years (2001-2018) in Piedmont, one of Italy's northern regions. The community empowerment (CE) approach discussed here involved two main interventions. First, a regulation that was issued to forbid the hunting of overabundant species counterintuitively eliminated the interest of hunters in artificially increasing wild boar population growth via illegal releases. Second, increasing amounts of responsibility for controlling the wild boar population were delegated from government institutions to the local community, where volunteers (including nonhunters) were provided depredation permits outside the regular hunting season. Via in-depth interviews and observations to gather qualitative data, we trace the lessons learned during implementation of the $\mathrm{CE}$ approach. In particular, we illustrate how structured decision making was consequential in bringing forth higher order learning via iterations in three districts with different local regulations regarding wild boar hunting (hunting was permitted in only two of the districts). We find lower boar populations and lower economic damage from boar in the district without hunting, suggesting that a regulation allowing hunting (especially hunting with the help of hounds) actually increases the overall population via incentivizing illegal releases. In the two districts permitting hunting, the successive delegation of responsibility to the local community proved most effective in legally reducing illegally released wild boar. We discuss implications for effective management of overabundant species.
\end{abstract}

Key Words: human dimensions of wildlife; hounds; illegal behaviors; law enforcement; overabundant resources; regulations and policies; wild boar

\section{INTRODUCTION}

Scholars, practitioners, and international conventions such as the Convention on Biological Diversity (https://www.cbd.int) and the Convention on International Trade in Endangered Species of Wild Fauna and Flora (https://cites.org/eng/disc/text.php) acknowledge the accelerating loss of biological diversity and the need for measures to protect ecosystems (Constantino 2016). Legal principles worldwide recognize human interdependency with the natural environment and the necessity of considering future generations in current resource management decisions (Hare and Blossey 2014, Decker et al. 2016) because humans must be seen as a part of, not apart from, nature (Berkes and Folke 1998). Illegal activities such as overfishing, poaching, and poisoning directly affect natural resource use, threaten fauna species, and have a negative effect on measures intended to preserve the natural environment. Combatting these illegal behaviors represents a key challenge in modern society (Critchlow et al. 2015, Duffy et al. 2016), and law enforcement constitutes an essential element of current conservation efforts (Linkie et al. 2014, Plumptre et al. 2014), at least in theory. In practice, however, a recurrent issue in natural resource management is that the territories to patrol are vast and the activities to be monitored are many, whereas resources to do so are often severely constrained.

When a society's focus is on protecting wild fauna, illegal behavior needs to be added to the equation for effective management (Bunnefeld et al. 2011). In response, researchers have studied how to position patrols in the best locations (Dhanjal-Adams et al. 2016), in particular, as a means for reducing retaliatory killing of species that cause economic damage (Treves et al. 2009, Can et al. 2014). Combatting illegal activities in the context of endangered and vulnerable species is clearly important for their preservation (Bennett 2011). However, it is equally important to combat illegal activities affecting species of "least concern" (Chee and Wintle 2010) on the International Union for the Conservation of Nature red list (http://www.iucnredlist.org/) because such activities can have subsequent repercussions on the surrounding biota and local societies. This category of illegal acts has attracted fewer studies than those against endangered and vulnerable species.

The wild boar (Sus scrofa) is an interesting example of such leastconcern species. Ironically, the wild boar has turned the notion of "least" concern on its head by becoming overabundant, and the "concern" has moved from conservation to curbing economic and ecological damages caused by the species. Its population has grown significantly throughout Europe in recent decades (Massei et al. 2015), it is expanding in the United States, and is threatening native species (Snow et al. 2017). The main biological reasons for the wild boar's proliferation include its reproductive rate, which may exceed 2.0 young/yr (Bieber and Ruf 2005); its adaptability to different habitats (Geisser and Reyer 2005), including cities (Stillfried et al. 2017); its diversified diet (Schley and Roper 2003); and its lack of natural predators, apart from the wolf, once weaned (Servanty et al. 2011). Illegal releases for recreational hunting, often with nonautochthonous species, can alter the genetic makeup of the existing population and further contribute to an increase in population (Scandura et al. 2011). Whatever its causes, high concentrations of wild boar cause damage to agriculture, increase the risk of car accidents, and affect local ecosystems (Geisser and Reyer 2004, Barrios-Garcias and Ballari 2012), making it essential to identify tools and strategies for reducing populations (Massei et al. 2011, Frackowiak et al. 2013).

${ }^{1}$ USI Università della Svizzera italiana, ${ }^{2}$ USI Università della Svizzera italiana, Institute of Marketing and Communication Management, ${ }^{3}$ Studio Associato AlpVet 
Hunting is among the leading causes of wild boar mortality (Toïgo et al. 2008, Keuling et al. 2013), yet it is also among the most controversial management methods. For example, a recent literature review shows that hunting has failed to achieve a "drastic reduction in a wild boar population" (EFSA 2014:2). Amazingly, wild boar facing high hunting pressure seem to adapt in ways that increase the survival of the species, e.g., via younger age and smaller size at first reproduction (Toïgo et al. 2008, Servanty et al. 2009). Hunting also raises ethical issues (Nurse 2016) and is at the core of conflicting stakeholder opinions on how fauna should be managed (Decker et al. 2012, Yasuoka et al. 2015). Conflicts in a community are further exacerbated when hunters artificially (and illegally) augment local wild boar populations to supplement recreational hunting stocks (Spencer and Hampton 2005) by releasing bred boar into the forest.

Releasing fauna into an environment may pose several threats if uncontrolled: it may alter local genetic structures (Scandura et al. 2011), affect local flora and fauna (Foster et al. 2014), and foster stakeholder defiance of authorities (Pohja-Mykrä 2016). Such releases are therefore typically regulated by law based on scientific evidence (Fernández et al. 2006). However, some stakeholders obtain personal benefits from the release of certain species and avoid considering the broader impact of the practice. Here, we examine the Piedmont region in northwestern Italy, where breeding of boar for restocking purposes has been illegal since 1989 (Piedmont Regional Law 47/1989: http://arianna. consiglioregionale.piemonte.it/ariaint/TESTO?LAYOUT $=$ PRESENTAZIONE\&TIPODOC=LEGGI\&LEGGE=47\&LEGGEANNO=1989, and subsequently, 09/2000: http://arianna. consiglioregionale.piemonte.it/base/coord/c2000009.html). Despite this illegality, the Verbano-Cusio-Ossola (VCO) province has "undoubtedly" suffered substantial illegal releases "until recent years," causing the hybridization of local wild boar with southern Italian and even Asian species (Regione Piemonte 2008:39). Previous studies have mainly looked to illegal releases of bred animals (often involving hybrids of domestic and wild boar) from quantitative biological perspectives, considering their effect on population sizes, survival rates, and DNA mutations, with less attention to the social and human dimensions behind such releases. Thus, we focus squarely on the motivations at the base of these releases, their effects on local human communities, and the responses they generate from environmental policy and regulation perspectives.

In our case, these releases aggravated already existing conflicts and represented a significant challenge for the resource-stripped local management. Addressing this issue involved delegating increasing responsibility for controlling the wild boar population from the central government to the local community, where volunteers (even nonhunters) were provided depredation permits outside the regular hunting season. As other work has shown, studying illegal behaviors poses problems of data access and requires methodological innovation (Gavin et al. 2010, El Bizri et al. 2015). We used in-depth qualitative data from interviews and direct observations to trace the iterations of resource management in the face of high uncertainty and high controllability (Berkes et al. 2000, Allen et al. 2011). In particular, we illustrate how structured decision making was consequential in bringing forth higher order learning via iterations in three districts with different local regulations regarding wild boar hunting (hunting was permitted only in two of the districts). Counterintuitively, we find that allowing hunting actually increased the overall population also via incentivizing illegal releases, as demonstrated by lower populations and lower economic damage in the district without hunting. In fact, in the two districts permitting hunting, the successive delegation of responsibility to the local community proved most effective in legally reducing illegal releases of wild boar.

Strategies that directly rely on local communities for the management of natural resources have experienced a "crisis of identity and purpose" (Dressler et al. 2010:6). Researchers have attempted to find "approaches to environmental governance capable of confronting landscape-scale problems in a manner both flexible enough to address highly contextualized SESs [social-ecological systems] and dynamic and responsive enough to adjust to complex, unpredictable feedbacks between social and ecological system components" (Chaffin et al. 2014:1). Italy is an example of a state that resists modifications to its governance structure and has limited possibilities for bottom-up environmental management solutions. With a national law for the management of wild, warm-blooded animals dating back to 1992, a top-down governance structure, and an economic crisis started at the beginning of the new century, Italy represents a telling case example in which relying on local communities acts as a strategy for getting around the issue of lack of resources in rigid legal systems. The lessons learned from this case, therefore, have potential relevance in other places where overabundant populations of boar have become a problem for local ecological systems and human-related activities, such as in Luxemburg or Australia (Spencer and Hampton 2005, Schley et al. 2008), and for other huntable species affected similarly by illegal releases, including red deer (Cervus elaphus) in Ireland (Carden et al. 2011).

\section{STUDY AREA AND METHODS}

\section{Study area}

The study area is the VCO province $\left(46^{\circ} 07^{\prime} \mathrm{N}, 8^{\circ} 17^{\prime} \mathrm{E}\right), 2255$ $\mathrm{km}^{2}$ located in the northeasternmost part of the Piedmont region, close to the border of Switzerland, in the central Italian Alps (Fig. 1 , Table 1). Its territory is mainly mountainous $(79 \%$ is $1000 \mathrm{~m}$ above sea level), populated by typical alpine fauna and a prevalence of oaks and chestnuts. Average annual rainfall is abundant (1200-2500 mm/yr) and is concentrated in summer. The climate is sub-Atlantic in the south and more alpine in the north; some areas near Maggiore Lake and Toce River have a Mediterranean climate (Regione Piemonte 2013:14-15).

Although wild boar had been absent from the Piedmont region since the 17th century, it reappeared in 1919 (Bassano et al. 1995, Hearn et al. 2014). Its exact arrival in VCO is uncertain but is commonly thought to be in approximately 1970, based on interviews with local stakeholders. The main drivers of its population growth in the area include the favorable climate, habitat and food conditions (in large part because of the indigenous chestnut forests), and releases of bred boar for hunting purposes (which have been illegal since at least 1989).

As of 1996, VCO is divided into three hunting districts (VCO1, $\mathrm{VCO} 2$, and $\mathrm{VCO} 3$ ), each chaired by a committee "charged with wildlife management and hunting organization" (Piedmont Regional Law 70/1996, http://arianna.consiglioregionale.piemonte. 
Table 1. Verbano-Cusio-Ossola (VCO) province hunting district characteristics, including habitat, numbers of hunters and volunteers, hunting fees, and cost of damages to meadows and pastures caused by wild boar.

\begin{tabular}{|c|c|c|c|}
\hline \multirow[b]{2}{*}{ Characteristic } & \multicolumn{3}{|c|}{ Hunting district } \\
\hline & $\mathrm{VCO} 1$ & $\mathrm{VCO} 2$ & $\mathrm{VCO} 3$ \\
\hline Hunting agro-silvo-pastoral area & 44,299 ha & 43,495 ha & 53,894 ha \\
\hline Deciduous forest (300-1300 m above sea level) & $43 \%$ & $19 \%$ & $23 \%$ \\
\hline Coniferous forest (1300-2200 $\mathrm{m}$ above sea level) & $1 \%$ & $17 \%$ & $13 \%$ \\
\hline Rupicolous grassland ( $>2200 \mathrm{~m}$ above sea level) & $2 \%$ & $9 \%$ & $5 \%$ \\
\hline Meadow and pasture abundance & $6 \%$ & $14 \%$ & $10 \%$ \\
\hline Mean number of hunters (2003-2016) & 584 & 408 & 663 \\
\hline Number of enrolled "volunteers" (2016) & 89 & 34 & 76 \\
\hline Hunting fee to the district (2016) & $130 €$ & $150 €$ & $140 €$ \\
\hline Fee to hunt wild boar (Sus scrofa; 2016) & $100 €(25 \mathrm{head} / \mathrm{yr})$ & Not allowed & $50 €(25$ head/yr $)$ \\
\hline Fee to hunt roe deer (Capreolus capreolus; 2016) & $220 €(3$ head $)$ & $120 €(1 \mathrm{male})$ & $150 €(1$ male $)$ \\
\hline Fee to hunt stags (Cervus elaphus; 2016) & $350 €(2$ head $)$ & $300 €(1 \mathrm{male})$ & $300 €(1 \mathrm{male})$ \\
\hline Fee to hunt chamois (Rupicapra rupicapra; 2016) & $200 €(2$ head $)$ & $150 €(1 \mathrm{male})$ & $150 €(1$ male $)$ \\
\hline $\begin{array}{l}\text { Refunded damage to meadows and pastures (2004 } \\
2014 ; \text { mean } \pm \text { standard deviation) }\end{array}$ & $26,335.10 \pm 9028.30 €$ & $7203.00 \pm 4436.33 €$ & $14,439.80 \pm 6583.72 €$ \\
\hline
\end{tabular}

\section{it/ariaint/TESTO?TIPOVISUAL $=$ XML $\&$ LAYOUT $=$}

PRESENTAZIONE\&TIPODOC $=$ LEGGI\&RINVIOPDL $=0 \&-$ $\underline{\mathrm{LEGGE}}=70 \& \mathrm{LEGGEANNO}=1996$ ). Local regulations in VCO1 and VCO3 have permitted the hunting of wild boar since 1996, allowing hunting by teams or individuals and with or without hounds, but only during daytime and on specific days of the hunting season. Each hunter must pay an annual registration fee to the district, plus a fee for each ungulate individually, including wild boar. Hunting wild boar with hounds is particularly prevalent in VCO1, where individual hunting teams keep packs of short-legged dogs (purebreds as well as hybrids of the segugio maremmano breed) bred specifically for chasing wild boar.

Fig. 1. Map of Italy, showing the Piedmont region and the location of the Verbano-Cusio-Ossola (VCO) province hunting districts.

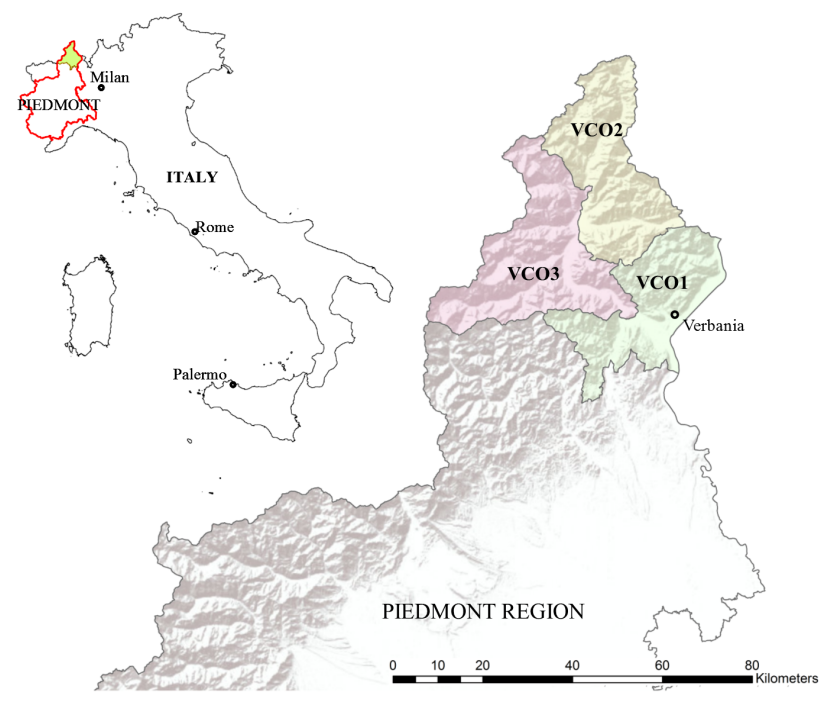

VCO2's regulations have followed a different path. As in VCO1 and $\mathrm{VCO} 3$, each hunter pays a registration fee, plus a fee for hunting a selected ungulate species (chamois, roe deer, and red deer) though not wild boar. In fact, whereas hunting of wild boar was allowed until 2000, it has been prohibited since 2001. Only incidental takings have remained possible. Thus, while there are no hunting days specifically for wild boar, if a wild boar happens to cross the hunter's path while hunting other ungulates, the hunter is allowed to shoot that animal incidentally. Hunters, however, are disincentivized to shoot wild boar during the regular hunting season for two reasons. First, hounds are not allowed for hunting wild boar, making chance encounters of wild boar very unlikely. Second, even if such a chance encounter takes place, hunters typically refrain from shooting that animal for fear of scaring away other ungulates which they actually paid to hunt. As Luca Rotelli (a wildlife technician in the VCO province for the wildlife service of the Piedmont region from 1998 to 2010) explains, one of the main reasons for discouraging hunters from going after wild boar "was that we did not want people to buy and release new heads for their entertainment for the following hunting season. We wanted to prevent hunting wild boar from becoming attractive" (16 September 2016 interview).

Whereas each of these regulations applies in a single hunting district (district level), in 2010, VCO province (province level) introduced a new strategy, which applied to all three districts uniformly, with the objective of containing the growing wild boar population. This management system can best be translated as "community empowerment" (CE) and has created a capillary network of volunteers who cooperate with the province's police force to reduce wild boar numbers and their damage. The main purpose, as declared by Riccardo Maccagno (provincial police commander from 2012, and previously, vice-commander), "was to create a system able to reduce wild boar numbers, their damage, and, importantly, to stop illegal releases" (29 October 2015 interview). The system entailed the successive delegation of responsibility for boar management to the local community (see Discussion). In particular, it entailed the selection and nomination by the province of two new subjects: (1) volunteers (coadiutori), who are landowners with valid hunting licenses who are 
Fig. 2. Means-end linkage diagram applied to the Verbano-Cusio-Ossola (VCO) province hunting districts. The diagram is inspired by Decker et al. (2012:95).

\begin{tabular}{|c|c|c|c|c|}
\hline 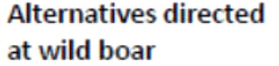 & $\begin{array}{l}\text { Enabling objective } \\
\text { directed at wild boar }\end{array}$ & 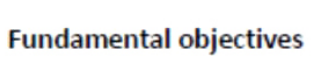 & $\begin{array}{l}\text { Enabling objective } \\
\text { directed at people }\end{array}$ & le \\
\hline
\end{tabular}

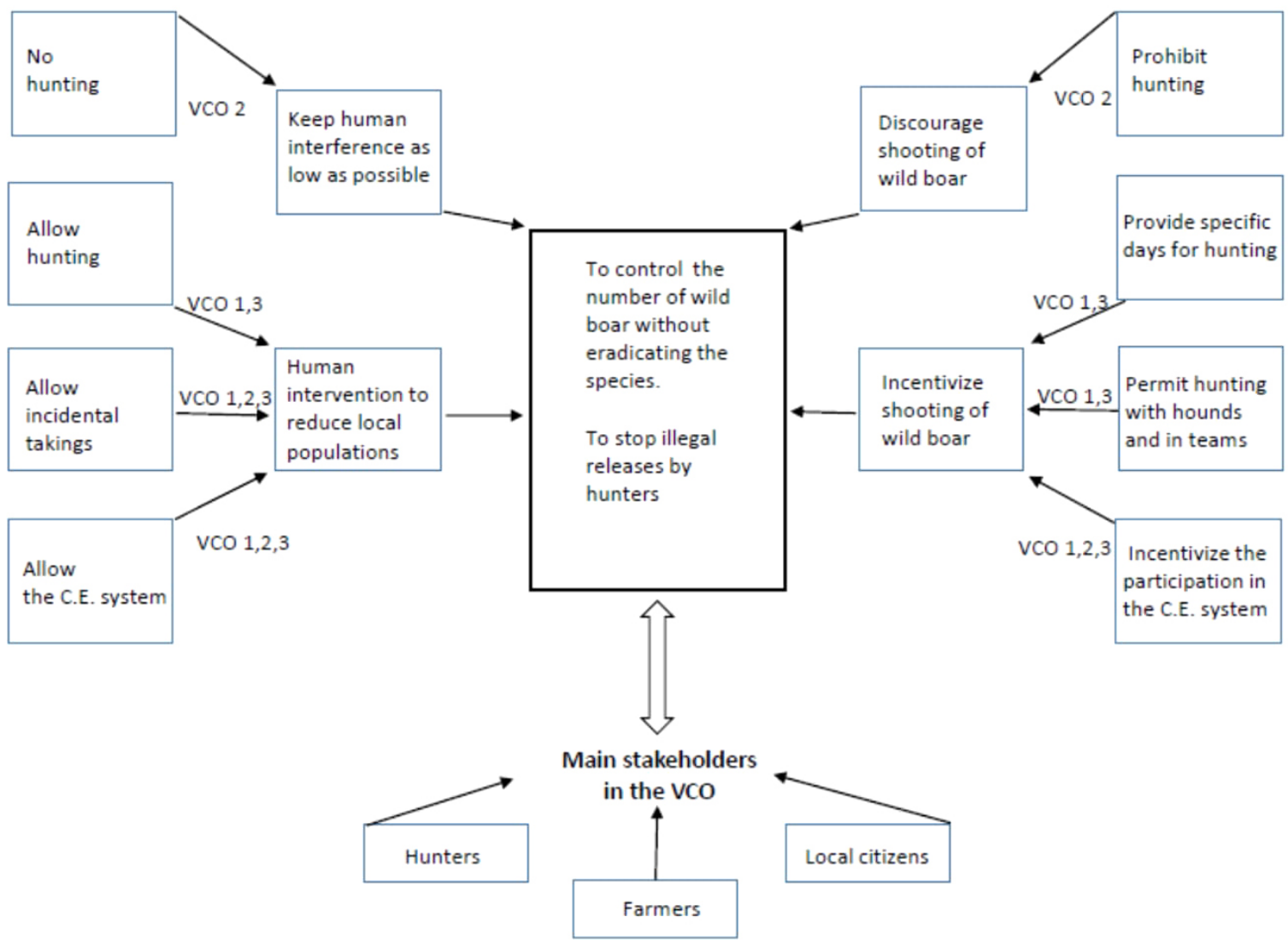

authorized to shoot wild boar outside of the hunting season, even at night, though only on their own land; and (2) referents (referenti). In practice, this involved issuing predation permits to citizens with the necessary prerequisites, in particular, a valid gun permit and insurance coverage. To obtain such permits, volunteers and referents had to send an SMS message to the provincial police (polizia provinciale) by noon of the day during which the intervention would take place. To maximize control, every single shot fired during the intervention, as well as its results, had to be immediately reported via SMS message to the authorities, and once the intervention was over, and irrespective of its outcome (i.e., whether or not one or several wild boar were harvested), another SMS message had to be sent. The depredation permits initially enabled volunteers to cull wild boar where and when they appeared on land either owned or managed by these individuals. In a second stage, the CE system extended the geographical reach of these activities beyond the property of the volunteers such that wild boar could be shot anywhere and at any moment in time, following prior authorization (using the same SMS system) by the local wildlife management authorities (provincial police). The only restriction to this general rule was that depredation permits would not be issued to referents or volunteers the evening before a regular hunting day. This was a concession to the hunting community, with two objectives. First, the intention was to minimize disturbance of other huntable species the night before a hunting day would start. Second, it created maximum transparency of and trust in the CE system by the hunting community; not even those most ardently opposed to the CE system could claim that volunteers and referents would abuse the wild boar permits to poach other ungulates at night and then conveniently declare them as having been harvested legally in the morning hours, i.e., when the hunting day officially started during the hunting season.

Before the introduction of the CE system, damage to agriculture or private property could only be addressed by calling the provincial police and asking for their intervention, which required sending several officers to the field to neutralize problematic animals. The main disadvantage of this approach was that there were simply not enough officers to cover $2255 \mathrm{~km}^{2}$, and so there were often long delays (days or even weeks) before the requested intervention could be provided. Frequently, when agents arrived, 
the problem reoccurred elsewhere. Volunteers' incentives included being able to keep the carcass of the animal, which could then either be sold or kept for family consumption (within the legal framework of the law Reg. CE 853/2004; see Viganò et al. 2017), as well as a sense of civic duty (Asah and Blahna 2012, Lab 2014). As one volunteer explained, "I have accepted to be part of the CE system because I felt sorry for seeing an old woman's vegetable garden destroyed by wild boar year after year, and so I have accepted the call of making use of my gun license for the sake of my neighbors" (8 February 2016 interview, anonymous volunteer). Fig. 2 provides a schematic representation of the concurrent regulations present in VCO today.

\section{Methods}

We use a nested case study design (Lieberman 2005, Yin 2008) in which three comparable cases' regulations (VCO1, VCO2, and VCO3) are embedded in one province's (VCO) superordinate regulations. Data are then analyzed in replication mode (Eisenhardt 1989) following, in particular, Gibbert et al.'s (2008) criteria for rigorous case study research. That is, we developed the initial theoretical model using VCO1, where hunting was actively encouraged, and then analyzed VCO3, which had similar hunting regulations, using confirmatory (literal replication) logic. We moved on to theoretical replication with $\mathrm{VCO} 2$, which, importantly, differs from the other two districts in that it does not permit hunting of wild boar. The superordinate CE system represents a type of manipulation in the sense that it allows us to compare effectively the periods before (a baseline condition) and after (the treatment condition) the introduction of the system (in 2010) in each of the three districts, thus, allowing a systematic within-case and between-case analysis.

Each case study drew on archival data (provided by the Osservatorio Faunistico Regione Piemonte, VCO province, and each district), interviews with participants in the various stakeholder groups, and direct as well as participant observation. For validity and reliability, we triangulated observation and interview derived data across researchers, comparing notes and impressions. In particular, the first and second authors participated simultaneously as volunteers in the CE system during the time of the research and they independently collected data as hunters in the regular hunting sessions (the second author from 2009-2015 and the first author from 2016-2018). The third author is a veterinarian who has been working since 2003 as a technician in centers for the verification of hunted animals (centri di controllo) in the Alps, and on projects related to animal management and health. These different roles, independently and jointly, were essential in developing a deep understanding of local regulations and their implementation. As in other studies conducted in rural settings and involving prototypical rural activities such as hunting (e.g., Bye 2009), combining interviews with observations allowed the researchers to gain high-quality data and insight into a notoriously difficult to observe phenomenon. Interviews were semistructured to obtain the information needed but also to maintain flexibility on aspects relevant for the interviewee (Legard et al. 2003). Interviewees included officials at the province and district levels, hunters, volunteers, and referents. Selection of interviewees followed a snowball sampling technique (Biernacki and Waldorf 1981), where we started with the province level's senior administrators. As the interviews proceeded, we asked the officials for names of new potential interviewees in the community, which in turn led to further opportunities for data collection. To develop an indepth understanding of stakeholders' interests, we specifically sought to triangulate interview data from participants with significant first-hand experience (1) only as hunters, (2) only as volunteers or referents, and (3) both. This iterative exercise yielded 28 in-depth interviews, the most relevant excerpts of which are reported here in our own translation; direct and participant observations of $>40$ hunting sessions over nine years (20092017); and several CE system sessions.

As in other qualitative studies of the human dimensions of wildlife management (Decker et al. 2012, Hayward et al. 2015), we found it challenging to obtain reliable data (i.e., data that can represent the true situation and so on which it is reasonable to base assumptions), especially on illegal activities (Gavin et al. 2010). Even more so than is common in ethnographic studies generally (O'Reilly 2012), most interviewees had a certain level of suspicion toward the research. As a result, participants demanded "off the record" confidentiality in exchange for allowing further data collection and observations.

Our dependent measure was the Euro amount refunded by the state (as required by National Law 157/1992, http://www. gazzettaufficiale.it/eli/id/1992/02/25/092G0211/sg) to indemnify farmers for damage caused by wild boar to agriculture in general and to meadow and pasture cultivation in particular. The VCO area is a perfect location to investigate this aspect because the three districts have comparable geography and are adjacent. Therefore, to detect the economic implications of a nonhunting regulation, we focused on $\mathrm{VCO} 2$ refunds paid by the state to indemnify farmers for damage to their cultivation. Whereas general agriculture combines several types of cultivation (e.g., vineyards, potato fields, fruit gardens) and provides an overview of VCO-refunded damage, we selected meadow and pasture cultivation as our measure for two reasons. First, it is a type of cultivation present in all three districts. Second, it is one of the main signs of the presence of wild boar in an area. We selected the period of 2004-2014 for analysis because data were not available before 2004, whereas from 2015, following the deliberation of 10 September 2015 in the Piedmont region, different procedures and refund levels came into force, rendering the subsequent period incomparable with previous years. We first ran an ANOVA to determine if the three districts differed significantly in the amount of Euros refunded by the state. We followed the ANOVA with a Scheffè post-hoc test to ascertain if each district had a statistical difference in the amount of Euros refunded from the other two districts considered separately. Finally, we considered the mean damage suffered by each district.

Looking at trends in population increases and decrease in the three districts before and after 2010 (i.e., 2001-2009 vs. 2010 2016) and relying on qualitative data to capture the behaviors and moods of local stakeholders, we interpreted the results to assess the success of the nonhunting regulation in $\mathrm{VCO} 2$ and of the $\mathrm{CE}$ system across VCO1 and VCO3 in preventing hunters from releasing bred boar into the forests. As in other studies (EFSA 2014:Appendix A, Massei et al. 2015), we extrapolated wild boar population trends using hunting bags, which are the only available count instrument in the area, and by having the number of enrolled hunters in each district follow nonsignificant increases 
and decreases over the years. To ascertain if there was a correlation between the growth or decline in hunting bags and the time period considered, we ran a Spearman correlation test. However, we recognize that hunting bags are an indirect tool that provides estimations of trends and not precise numbers.

\section{RESULTS}

\section{1-2009}

The VCO1 wild boar population showed exponential growth, with a statistically significant temporal correlation (Spearman $\rho<$ 0.001 ). The trend began with 167 hunted boar in 2001 and peaked at 986 in 2008 (Fig. 3). The data in 2009 must be considered an outlier: heavy snows and a cold 2008-2009 winter caused high natural mortality throughout the Piedmont region (in 2008, almost 18,000 wild boar were shot in the region vs. almost 9000 in 2009).

Fig. 3. Trend in the number of wild boar bagged over time from hunting activity in VCO1 and VCO3 hunting areas and from incidental take in VCO2 hunting area from 2001 to 2009. There is a clear increasing trend in VCO1 and VCO3, and virtually no take in $\mathrm{VCO} 2$.

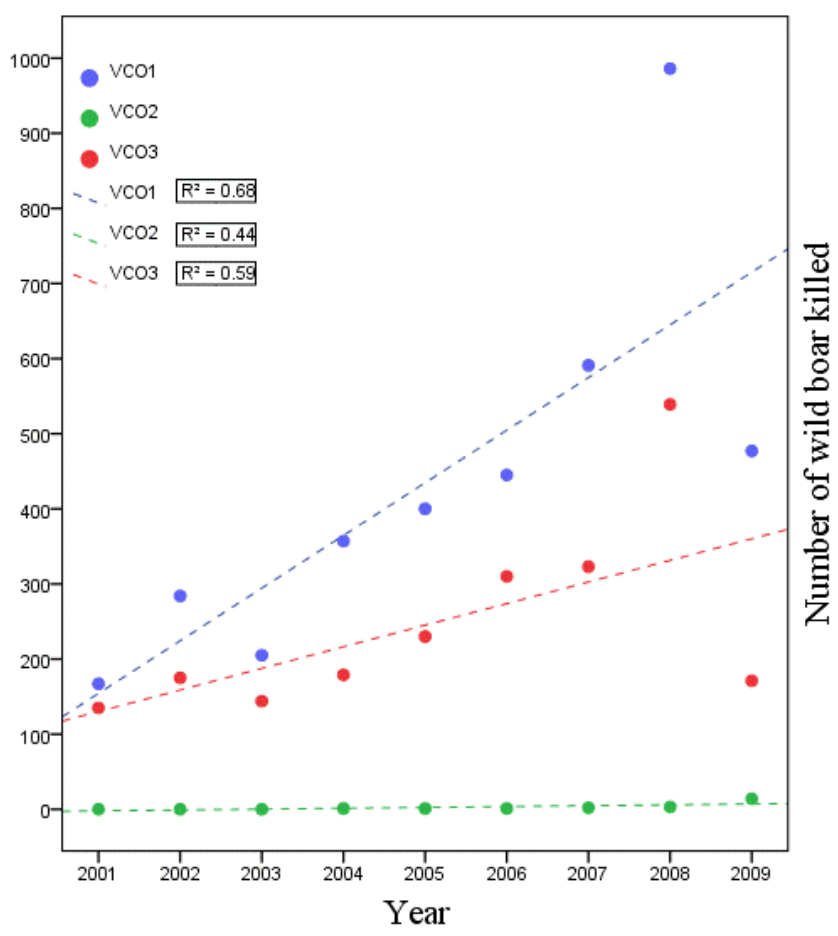

Local hunters' interest in the species seems to have occurred almost by chance. As one stakeholder recalled, "In the 1970s, in the Mottarone area [south VCO1], there was one individual who bred boar, and at a certain point these boar escaped, or - it is unsure - they were intentionally set free. Subsequently, someone recaptured a few of these relatively tame boar and freed them in the San Bernardino forest [west VCO1]. After some years, a group of boar started causing damage in Cambiasca municipality [central VCO1], generating frustration among citizens. A team of hunters (of which I was part) was authorized to reduce their number. This was the spark of everything: hunters all of a sudden realized that it was fun to hunt wild boar, especially with the help of hounds. And word spread fast..." (5 November 2015 interview, anonymous respondent). Subsequent interviewees were asked about this starting event. One of them recalled these years: "I know some people who bought wild boar and then released them in forests to increase the stock of huntable animals. It was normal at that time. [...] Wild boar were mainly released by hunters," (7 October 2015 interview, anonymous respondent). Another interviewee admits to the behavior while also attempting to justify it (as in Pohja-Mykrä 2016): "For sure we have released wild boar, but it happened also in Switzerland [which borders the VCO province]. Moreover, wild boar constitutes a valuable resource for our territory because it reduces hunting pressure on other ungulates," (7 October 2015 interview, anonymous respondent). DNA studies seem to confirm these stories: "The genetic makeup of the population is very diverse and different from the rest of the Alpine areas [supporting the idea that] the situation is caused by recent introductions of alien heads [...] and not from natural migration of populations," (translated from Regione Piemonte 2008:39).

The wild boar population trend in VCO3 replicated that in VCO1: hunting bags in 2001 started with 135 killed wild boar, reaching 539 in 2008; 2009 data were outliers for the same reasons described above. As in VCO1, VCO3 stakeholders recall these early years with enthusiasm. As one stakeholder admits, "Some hunters started buying wild boar and releasing them in the woods because it was fun to hunt them half a year later. [...] Before the wild boar, there was little fun in hunting in the VCO," (11 February 2016 interview, anonymous respondent).

In the VCO2 district, where hunting was prohibited, wild boar population trends can be inferred by the incidental takings activity, which entails chance shooting, and amounted, in 2009 , to a grand total of 14 killed head. Local stakeholders can provide some additional insights. Prompted by the interviewer, one stakeholder admitted, "Of course there was the intent of some hunters to release bred boar in the area, and there was pressure on the district management committee to reopen the hunting. Nevertheless, hunting continues not to be allowed. So why release them if then you cannot shoot them?" (9 February 2016 interview, anonymous respondent). Data suggest, then, that the incidentaltakings-only policy seems to have been effective in disincentivizing hunters to go after the species. As one interviewee said, "I know of some hunters who pay the fee to hunt ungulates to have the chance to cull wild boar, but I feel they are a minority. Here we don't have the wild boar hunting culture," (9 February 2016 interview, anonymous respondent). Another interviewee confirmed this, "I don't like the idea of hunting wild boar with hounds. I know it's a necessity to obtain results, but hounds also disturb other ungulates. [...] Hunting with hounds should always be prohibited because untrained dogs start chasing any animal they find," (11 February 2016 interview, anonymous respondent). A central element in the wild boar hunting culture referred to above was the use of packs of hounds, in particular, the shortlegged segugio maremmano and its hybrids. Hunting teams would keep several of these dogs in kennels for three-quarters of the year, incurring significant expenses, and as such had a strong incentive to then "watch them work for at least a couple of days a year" (i.e., during the three-month hunting season), as several 
interviewees put it. This identification with the hounds was so strong that several hunters even used the names of a particularly efficient dog in their pack (sometimes years after the dog was gone) as nicknames within the team.

\section{0-2016}

Since the introduction of the CE system, the number of wild boar killed by regular hunting in VCO1 has stopped growing, bottoming out at 300 head in 2016 (Figs. 4 and 5).

Fig. 4. Trend in the number of wild boar bagged over time from hunting activity in VCO1 and VCO3 hunting areas and from incidental take in VCO2 hunting area from 2010 to 2016. There is a clear decreasing trend in VCO1 and VCO3, and virtually no take in $\mathrm{VCO} 2$.

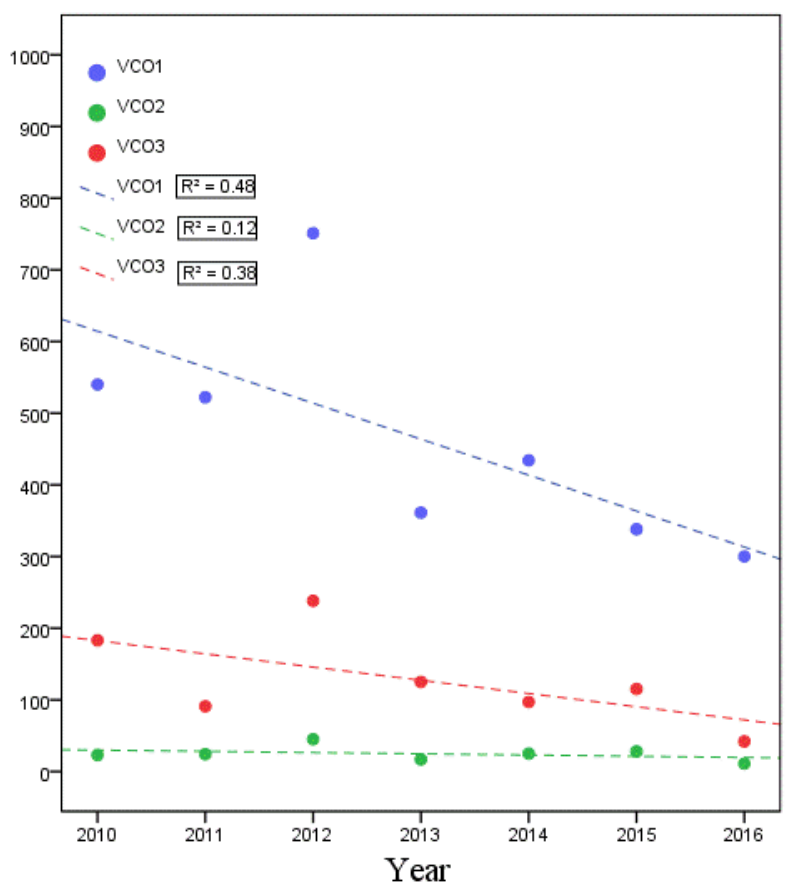

In the absence of an apparent biological explanation (e.g., disease, climate modification, food scarcity) other than the beginning of the CE system, the VCO1 hunting community has started directing their frustrations toward the volunteers and referents introduced in 2010. Some stakeholders were not shy to express their anger. Through drawing a comparison between a legal action and an illegal behavior one stakeholder opined, "Volunteers are worse than poachers. We should shoot them. [...] They register as volunteers under the CE system only because they want to hunt all year round," (7 October 2015 interview, anonymous respondent). The main driver for volunteers and referents was believed to be personal profit. "They have found a way to fill their freezer and sell meat during the whole year," (11 October 2015 interview, anonymous respondent). Volunteers seemed to disagree during interviews. One volunteer even invited the interviewer to look inside his freezer: "I don't care about the meat! I don't need to be enrolled in the CE system to fill my freezer. I can easily fill it during the regular hunting season. If you look into my freezer, you'll find lots of venison [other than wild boar] from previous years," (23 March 2016 interview, anonymous respondent). In addition, the economical aspect and the reduced number of animals to chase is addressed in a sort of "I pay and so I want to have fun" discourse. As an interviewee observed, "We pay our fees to the district for hunting boar, and those [...] volunteers reduce the number of animals we will find during the next hunting season. [...] Each year we find less and less wild boar. It's obvious: they are drastically reducing them," (7 October 2015 interview, anonymous respondent). Volunteers and referents, on the other hand, are willing to defend their positions. First, their civic engagement is invoked: "Today there are too many wild boar, and it is important to reduce their numbers because we need to reduce damage," (8 February 2016 interview, anonymous respondent). Then, volunteers felt the necessity to explain that their civic engagement is not well seen by all: "When I applied to the CE system, a group of hunters signed a petition to try to stop and intimidate me," (8 February 2016 interview, anonymous respondent). Finally, the economic issue and an alleged black market of wild boar meat is affirmed: "Hunters despise us because there are economic interests around wild boar hunting. Lots of hunters sell the meat, and of course we reduce their revenues. They don't understand ours is a civic duty, and they concentrate only on the fact that we reduce their prey and revenue," ( 8 February 2016 interview, anonymous respondent).

Fig. 5. Trend in the number of wild boar bagged over time from hunting activity and community empowerment activity in VCO1 and VCO3 hunting areas and from incidental take and community empowerment activity in VCO2 from 2010 to 2016. There is a decreasing trend in $\mathrm{VCO} 1$ and $\mathrm{VCO} 3$, and an inreasing trend in $\mathrm{VCO} 2$.

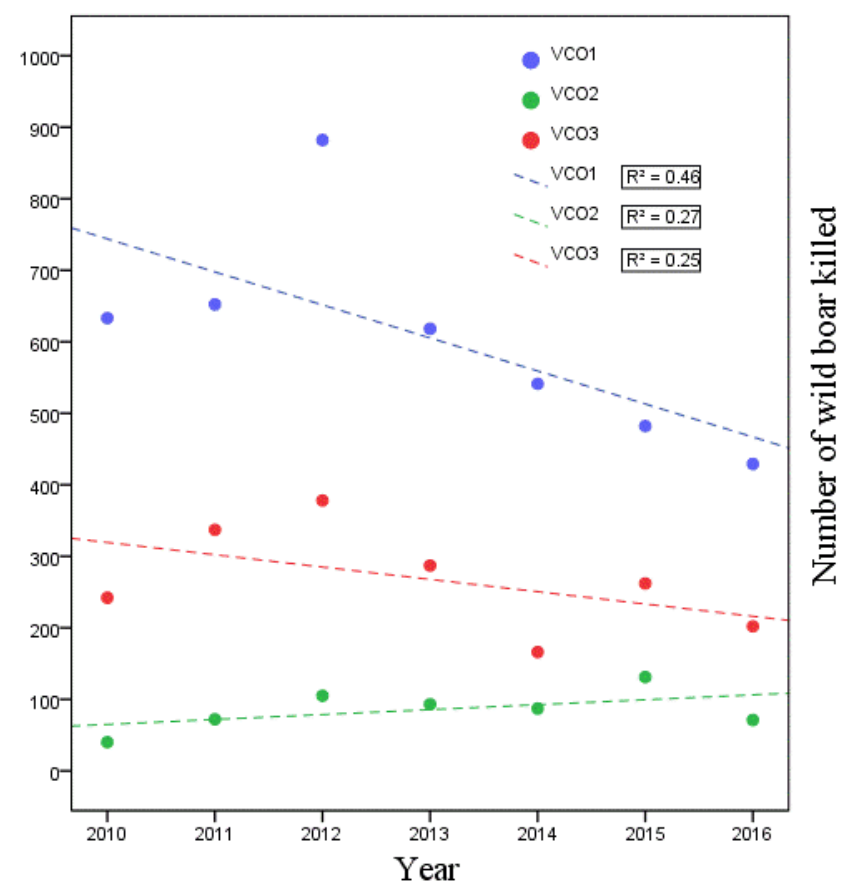

VCO3 faced a similar pattern: a change in the trend of the local wild boar population, which bottomed out at 42 individuals killed by hunting in 2016 . Here, once again, hunters' frustration has 
been directed toward volunteers and referents, who also relayed sabotage. "At the beginning, after my enrolment in the CE system, there were some people who entered my field at dusk and made lots of noise to make the wild boar [which I was stalking] run away. [...] Some hunters are so against reducing the wild boar population that I have found my traps broken open several times," (11 February 2016 interview, anonymous respondent).

The VCO2 wild boar population trend continued to remain uncertain because of the incidental-takings-only activity, resulting in between 11 and 29 head killed over the years. However, and in stark contrast with the other two districts, hunters and volunteers or referents did not refer to any conflicts. As a volunteer told us, "People here know that if there are problems with wild boar, we are swift in intervening and that we do true prevention," (9 February 2016 interview, anonymous respondent). "No, I don't have any conflicts with local hunters, but I know it's different in other places," (9 February 2016 interview, anonymous respondent). Another volunteer tries also to propose a motivation. "The fact that hunting is not allowed in VCO2 excludes all possible conflicts with hunters. On the contrary, volunteers have a strict bond with the local community," (9 February 2016 interview, anonymous respondent).

\section{Damage to agriculture}

As one hunter told us, "If you don't allow hunting wild boar, you'll find extraordinary damages to repay," (11 October 2015 interview, anonymous respondent). As such, it was important to clarify whether a nonhunting approach could result in more economic damage to human activities such as agriculture compared to a prohunting regulation. ANOVA results indicate that the cost of refunding damage to agriculture in general is significantly different among the three districts $(P<0.001)$, with the post-hoc Scheffè test showing VCO1 as different from VCO2 $(P<0.001)$ and VCO3 $(P=0.013)$, and VCO2 as different from VCO3 $(P<0.001)$. For each year, VCO2 was the district with the lowest amount of damage indemnified by the state. This result becomes more noteworthy when we consider meadows and pastures as a common cultivation for all three districts. VCO2 remains the district with the lowest amount of refunded damage, with 2014 as the only year in which VCO3 paid less. These results point to the fact that, even if $\mathrm{VCO} 2$ has a similar area dedicated to meadows and pastures compared to VCO1 and VCO3, and no other variables seem to interfere (e.g., the presence of extensive fenced fields or unfavorable environmental conditions), VCO2 farmers generally report less damage to their cultivations and the $\mathrm{VCO} 2$ district suffers less damage to its agricultural fields than the other two districts (Fig. 6).

\section{DISCUSSION}

\section{Management framework}

Here, we provide a post-hoc sense-making of the results, i.e., what can be learned from the management approach outlined here, what the alternative paths were, and which considerations led to the implementation of the chosen path. While the study was not initially set up to follow the principles of adaptive management (AM; Gunderson and Light 2006, Allen et al. 2011), we subsequently decided to loosely draw on AM frameworks to relay the main decision points effectively ("What is the factor in boar management that determines success?"), and the alternative approaches that could be used to manage boar if the first strategy did not deliver the expected results (the adaptive aspect of management). AM is often confused with "learning by doing" (e. g., Allen et al. 2011). This is not surprising because both share a concern for organized, transparent, decision-making processes for identifying and evaluating alternatives and for justifying complex decisions based on evidence. The key differentiator, however, is the opportunity to learn, ultimately increasing system knowledge via a structured feedback process involving (scientific) evidence. The result is a virtuous circle characterized by iterative (rather than linear) learning, and where, after a decision is implemented, extensive monitoring occurs, which in turn leads to an evaluative phase in which adjustments are made based on that learning. Subsequently, the problem is (re-)defined, and a successive iteration of structured decision making starts (again by defining the "new" problem, objectives, evaluation criteria, etc.). This process can be observed in our case as follows (for an illustration of the circular process that pertains to the AM framework, see Allen et al. 2011).

Fig. 6. Amount (in Euros) refunded to farmers by the state for damages caused by wild boar to agriculture in general (Total_damages) and to meadows and pastures in particular in the three VCO hunting districts during 2004-2014. Both VCO1 and VCO3 had greater mean reimbursed amounts for damages than VCO2, even though boar hunting is forbidden in VCO2.

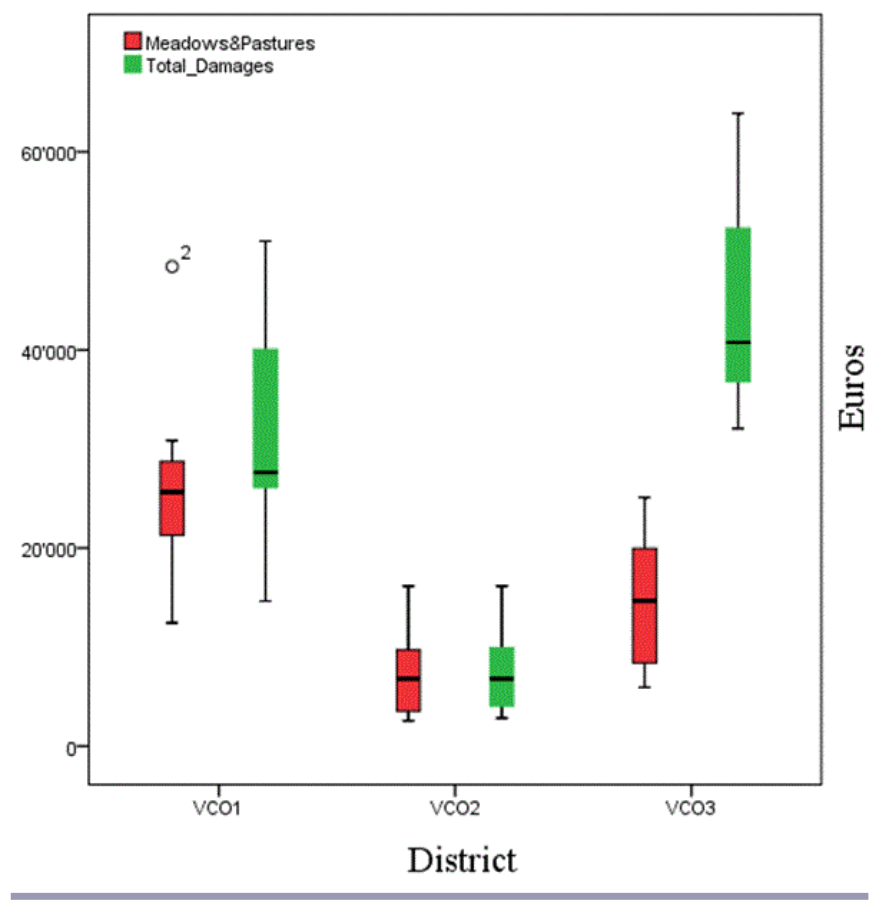

First management iteration: empowering volunteers

The starting point of the CE management approach clearly was the careful definition of the problem. At first sight, this seemed to be simply the increasing population of wild boar in the case study context. At a deeper level, this increase in population was in no small measure related to confirmed (via DNA analyses) illegal releases of wild boar for recreational hunting, as well as inappropriate hunting policies, in no small measure the allowing 
of hunting with packs of hounds. These two levels had to be considered in identifying the objective. The overall objective was to reduce the population and thus reduce economic damages to agriculture. Traditional hunting regulations were only partly effective in doing so. In fact, hunting seemed even to be counterproductive, as evidenced by the large populations (as estimated via the large hunting bags) in the VCO1 and VCO3 districts compared to VCO2, where hunting was not permitted, and where we saw least damage and the smallest number of boar killed. As one interviewee suggested, "There is no reason for doing illegal releases if then you cannot shoot the boar you have bought." At a deeper level, a secondary (though by no means less important) objective was to "nip illegal releases in the bud," as one interviewee put it. This objective was done via the first concrete measure, the introduction of volunteers. Formulating evaluation criteria seemed quite straightforward initially and focused on reducing the damage if and where it occurred, giving the individual experiencing the damage the possibility of responding immediately. The SMS system for issuing permits and tracking the number of killed boar is evidence for the high controllability aspect critical for adaptive management and proved effective in carefully monitoring the activities of volunteers. The estimation of outcomes was upbeat because bred boar are actually much less afraid of humans and therefore more easily harvested than their wild counterparts. This had the added benefit of further discouraging illegal releases because bred (tame) animals would be the first ones to be shot. Evaluating trade-offs included a careful consideration of the hunting communities. Clearly, these communities were less than pleased about the new system. This situation, however, was the price that local administration had to pay to provide immediate action toward solving the problem. However, the rule whereby depredation permits would not be issued the night before a regular hunting day would counterbalance the necessary alienation of the hunting community and ensure them of the transparency and legal compliance of the system. Thus, trade-offs were purposefully balanced with an eye on co-opting (rather than alienating) the hunting community. After implementation, several crucial lessons appeared. First, via monitoring who actually signed up as a volunteer, the local administration could separate out what they called "ethical" hunters from "nonethical" hunters. Nonethical hunters (those that actively released wild boar or passively condoned and profited from illegal releases) would clearly not sign up as volunteers. Monitoring further revealed that the volunteer system was only partially effective, simply because the volunteers were only issued depredation permits for their own land or land they managed. Thus, the range of volunteer activity was severely limited. Evaluating (again in the context of tradeoffs in terms of potentially alienating the hunting community even further) then led to the decision to adjust the volunteer system by scaling it up to include referents.

\section{Second management iteration: introducing referents}

The need for adjustment represented a key learning from the implementation of the volunteer program. Definition of the (new) problem here revolved mainly around the limited geographical reach of volunteers. As long as wild boar caused damage to property that was managed by a volunteer, and a depredation permit could be issued, the resource management system produced results. However, when damage occurred on a neighboring property, the volunteer in question could not intervene, and local administration simply did not have the resources to send wardens and police officials to the various problem zones. The objective of the second iteration, therefore, was to scale up the reach of volunteers beyond their home turf, quite literally speaking. The new actor was the referent, who basically acted as a go-between, linking volunteers with the provincial police and ensuring full coverage of the entire province on an on-demand basis. Evaluation criteria were key in this second iteration and were based on learning accrued from the first phase. The main issue was to reduce the number of call-outs the $\sim 11$ provincial police rangers received and to delegate management of the resource to the hub-and-spoke system involving referents and volunteers. Estimating outcomes and evaluating trade-offs pointed once more to an alienation of the hunting community. The response by the hunting community was understandably even more aggressive because "their" wild boar could now be shot anywhere. The outrage this caused was really a blessing in disguise (exactly as suggested in the learning from the first iteration) because it separated the "wheat from the chaff" even more effectively than did the first phase and singled out those individuals who clearly had no stake in illegal releases and were happy to "hunt all year round" as one interviewee, who was passionately against the CE system, derided.

Implementation and monitoring of this new system still revealed a number of cases in which referents and volunteers, while formally registered, often found excuses and actually were mostly unavailable to undertake action when required or repeatedly asked for depredation permits without ever shooting a single animal. This suggested that they simply wanted to occupy the place of someone with more genuine motivations. Adjustment included replacing these individuals with peers who were more actively engaged. The motivation of volunteers and referents, apart from practicing their sport outside the regular hunting periods and doing a service to the community at the same time, were based on the higher quality of meat obtained during nighttime depredation, when animals are typically harvested with a single shot (easily monitored at zero cost because volunteers and referents had to relay the exact number of shots fired as well as the number of animals harvested in real time via SMS message). In fact, one hunter told one of the authors that the dark-cutting meat resulting from regular hunting sessions involving dogs chasing the boar over extended periods and distances was "only fit for canine consumption." Overall, then, the lessons from the first iteration brought about significant improvements in the management of the resource as well as higher quality meat (and more humane harvesting of meat; see Viganò et al. 2017). Data collection stopped in March 2018, when, during a get-together of the volunteer and referent community, the provincial police commander, Riccardo Maccagno, presented the latest figures from the previous 12 months, which showed that in the 2017 season, approximately 1000 animals were harvested, of which approximately one-third was harvested via the CE system. The lessons from the previous two phases suggested bringing that proportion to a 50:50 split to reduce economic damage further.

\section{Region-wide adaptation of the community empowerment system and outlook}

While this manuscript was under review, a highly unexpected change (for the authors of this article) in the Italian legislative 
system occurred, which basically lifted the main tenets of the CE system to the regional level (our study was based on insights gained from only one of seven provinces in the Piedmont region). The new regional legislation (Piedmont Region Law of 19 June 2018, number 5, http://www.regione.piemonte.it/governo/ bollettino/abbonati/2018/25/attach/aa_aa_regione $\% 20$ piemonte $\%$ 20- $\% 20$ legge $\% 20$ regionale 2018-06-20 63715.pdf), in particular, at articles 20 and 22, provides the legal framework for the $\mathrm{CE}$ system to be adopted in provinces other than VCO. For example, in article 22, "extraordinary measures for wildlife management" clearly distinguishes between hunting and depredation activities for species causing damage.

The adaptation of the higher level legislation came as no small surprise for at least two reasons. First, the management of warmblooded, wild fauna is regulated by national law 157 dating back to 1992. During the subsequent 26 years, only small changes were introduced (mainly to comply with the European Union regulations). Second, Italian governance of natural resources follows a strict nested structure in which the flow of power is firmly top-down, i.e., from the state level, down to the regional level, and finally, to the province level, and there is little space for bottom-up innovation. For example, province-level legislation can only further constrain (and not derogate) regional-level rules. Similarly, regional-level laws cannot derogate national laws. An excellent illustration of this is the recent Constitutional Court (the highest judicial body in the country) ruling (number 139 of the year 2017, https://www.cortecostituzionale.it/actionSchedaPronuncia. do?anno=2017\&numero $=139$ ) that annulled a wild boar management system implemented by Liguria Region with the motivation that it would have derogated national law prescriptions. In many ways, then, the very rigidity of the Italian legislative system, combined with the severe lack of resources (only approximately 11 provincial police agents to cover the entire area under study) has led local management to "make virtue of necessity" (Gibbert et al. 2007, 2014), that is, to devise a nearly cost-free system for controlling the species within the constraints of the legal system. The CE system is not entirely cost free, of course, and resources, including vehicles and a minimum number of agents, are needed to keep it up and running, especially if the declared objective is to increase the number of wild boar harvested via the CE system from currently one-third to one-half. As such, an interesting final development in the CE system was to use it as a bargaining tool to obtain more resources: from August 2018, the pronvincial police suspended issuing depredation permits as well as any control of the wild board until further notice. Maccagno publicly declared, "We cannot continue to rely on our agents using their private cars for interventions. [...] We are in a season [the summer] where the problems will be felt, for instance in maize plantations, but we cannot go on like this," (translated from an interview in La Stampa [2018]).

To what extent the success of the CE system at the VCO province level has inspired regional-level legislation is beyond the scope of this article. However, the parallels are striking, to the extent that we may speculate that the wild boar issue can become the window of opportunity (Olsson et al. 2006) for a reform of the firmly topdown Italian wildlife management system toward a more decentralized and adaptive governance structure that would be more similar to the systems present in other countries (Decker et al. 2012:16).

\section{CONCLUSION}

Overall, illegal human activities (Mateo-Tomás et al. 2012, Critchlow et al. 2015) represent instances of high uncertainty and make effective law enforcement a key element of today's conservation efforts (Linkie et al. 2014, Plumptre et al. 2014). Investigating illegal acts is not easy because of their sensitive nature (Gavin et al. 2010), and previous studies have suggested that "the best way to improve law enforcement is to increase the probability of detecting illegal activities, particularly identifying the people involved and penalizing them" (Plumptre et al. 2014:715). Here, we have taken a different approach and described two other possible strategies: one aims at eliminating the motivation for illegal activities; the second extends, to local residents, the responsibility for watching over the ecosystem (Decker et al. 2012). The CE system was introduced as a solution for two districts (VCO1 and VCO3) where hunting was permitted, and its goals were "to split and break the hunting community, dividing ethical hunters from unethical ones, and to generate a conflict between them" (29 October 2015 interview, Riccardo Maccagno). Thus, our analysis combines ecological, social, management, and administrative aspects and suggests two possible management strategies to combat illegal releases, solutions that can be extended to huntable fauna in general and can potentially be adapted to the local social situation. Where feasible, wildlife institutions may opt to implement a nonhunting regulation for those fauna species susceptible to having their population growth artificially increased through (illegal) releases of bred individuals. If, however, a hunting culture is firmly rooted in the local society and it is extremely difficult or unpopular to change the policy, it is possible to rely on local communities and share the responsibility for fighting against illegal releases. The CE system described here can ultimately serve as a bargaining tool for cash-strapped local management, a lesson that may prove useful for other agencies.

\section{Responses to this article can be read online at: http://www.ecologyandsociety.org/issues/responses. php/10353}

\section{Acknowledgments:}

We thank officials and clerks at each district and at the VCO province level. In particular, we thank Luca Rotelli (wildlife technician in VCO for the wildlife service of the Piedmont region from 1998 to 2010) and Riccardo Maccagno (province police commander in VCO from 2012, and previously, vice-commander), who allowed us to use direct quotations to report their opinions. We further thank the anonymous reviewers who provided trenchant yet constructive comments. A special thanks is due to the seminar participants who provided useful comments at the Academy of Management 2017 Annual Meeting and The Wildlife Society's 24th Annual Conference. Last but not least, a particular thanks goes to the many hunters, volunteers, and referents who preferred to remain anonymous. The Fig. 1 VCO map was provided by Dr. Marco Gelati, University of Milano, Italy. Funding statement: This research did not receive any specific grants from funding agencies in the public, commercial, or not-for-profit sectors, or from private citizens. 


\section{LITERATURE CITED}

Allen, C. R., J. J. Fontaine, K. L. Pope, and A. S. Garmestani. 2011. Adaptive management for a turbulent future. Journal of Environmental Management 92(5):1339-1345. http://dx.doi. org/10.1016/j.jenvman.2010.11.019

Asah, S. T., and D. J. Blahna. 2012. Motivational functionalism and urban conservation stewardship: implications for volunteer involvement. Conservation Letters 5(6):470-477. https://doi. org/10.1111/j.1755-263X.2012.00263.X

Barrios-Garcias, M. N., and S. A. Ballari. 2012. Impact of wild boar (Sus scrofa) in its introduced and native range: a review. Biological Invasions 14(11):2283-2300. http://dx.doi.org/10.1007/ s10530-012-0229-6

Bassano, B., G. Boano, P. G. Meneguz, P. P. Mussa, and L. Rossi. 1995. I selvatici delle Alpi piemontesi: biologia e gestione. EdizioniEda, Turin, Italy.

Bennett, E. L. 2011. Another inconvenient truth: the failure of enforcement systems to save charismatic species. Oryx 45 (4):476-479. https://doi.org/10.1017/S003060531000178X

Berkes, F., J. Colding, and C. Folke. 2000. Rediscovery of traditional ecological knowledge as adaptive management. Ecological Applications 10(5):1251-1262. http://dx.doi. org/10.1890/1051-0761(2000)010[1251:ROTEKA]2.0.CO;2

Berkes, F., and C. Folke, editors. 1998. Linking social and ecological systems: management practices and social mechanisms for building resilience. Cambridge University Press, Cambridge, UK.

Bieber, C., and T. Ruf. 2005. Population dynamics in wild boar Sus scrofa: ecology, elasticity of growth rate and implications for the management of pulsed resource consumers. Journal of Applied Ecology 42(6):1203-1213. https://doi.org/10.1111/j.1365-2664.2005.01094. $\underline{\mathrm{X}}$

Biernacki, P., and D. Waldorf. 1981. Snowball sampling: problems and techniques of chain referral sampling. Sociological Methods and Research 10(2):141-163. http://dx.doi.org/10.1177/00491241$\underline{8101000205}$

Bunnefeld, N., E. Hoshino, and E. J. Milner-Gulland. 2011. Management strategy evaluation: a powerful tool for conservation? Trends in Ecology and Evolution 26(9):441-447. https://doi.org/10.1016/j.tree.2011.05.003

Bye, L. M. 2009. 'How to be a rural man': Young men's performances and negotiations of rural masculinities. Journal of Rural Studies 25(3):278-288. http://dx.doi.org/10.1016/j.

jrurstud.2009.03.002

Can, Ö. E., N. D’Cruze, D. L. Garshelis, J. Beecham, and D. W. Macdonald. 2014. Resolving human-bear conflict: a global survey of countries, experts, and key factors. Conservation Letters 7(6):501-513. https://doi.org/10.1111/conl.12117

Carden, R. F., C. M. Carlin, F. Marnell, D. Mcelholm, J. Hetherington, and M. P. Gammell. 2011. Distribution and range expansion of deer in Ireland. Mammal Review 41(4):313-325. https://doi.org/10.1111/j.1365-2907.2010.00170.x
Chaffin, B. C., H. Gosnell, and B. A. Cosens. 2014. A decade of adaptive governance scholarship: synthesis and future directions. Ecology and Society 19(3):56. http://dx.doi.org/10.5751/ ES-06824-190356

Chee, Y. E., and B. A. Wintle. 2010. Linking modelling, monitoring and management: an integrated approach to controlling overabundant wildlife. Journal of Applied Ecology 47 (6):1169-1178. https://doi.org/10.1111/j.1365-2664.2010.01877.x

Constantino, P. A. L. 2016. Deforestation and hunting effects on wildlife across Amazonian indigenous lands. Ecology and Society 21(2):3. http://dx.doi.org/10.5751/ES-08323-210203

Critchlow, R., A. J. Plumptre, M. Driciru, A. Rwetsiba, E. J. Stokes, C. Tumwesigye, F. Wanyama, and C. M. Beale. 2015. Spatiotemporal trends of illegal activities from ranger-collected data in a Ugandan national park. Conservation Biology 29 (5):1458-1470. https://doi.org/10.1111/cobi.12538

Decker, D. J., S. J. Riley, and W. F. Siemer. 2012. Human dimensions of wildlife management. Second edition. Johns Hopkins University Press, Baltimore, Maryland, USA.

Decker, D., C. Smith, A. Forstchen, D. Hare, E. Pomeranz, C. Doyle-Capitman, K. Schuler, and J. Organ. 2016. Governance principles for wildlife conservation in the 21 st century. Conservation Letters 9(4):290-295. https://doi.org/10.1111/ conl.12211

Dhanjal-Adams, K. L., K. Mustin, H. P. Possingham, and R. A. Fuller. 2016. Optimizing disturbance management for wildlife protection: the enforcement allocation problem. Journal of Applied Ecology 53(4):1215-1224. http://dx.doi.org/10.1111/1365-2664.12606

Dressler, W., B. Büscher, M. Schoon, D. Brockington, T. Hayes, C. A. Kull, J. McCarthy, and K. Shrestha. 2010. From hope to crisis and back again? A critical history of the global CBNRM narrative. Environmental Conservation 37(1):5-15. http://dx.doi. org/10.1017/S0376892910000044

Duffy, R., F. A. V. St John, B. Büscher, and D. Brockington. 2016. Toward a new understanding of the links between poverty and illegal wildlife hunting. Conservation Biology 30(1):14-22. https:// doi.org/10.1111/cobi.12622

Eisenhardt, K. M. 1989. Building theories from case study research. Academy of Management Review 14(4):532-550. http:// dx.doi.org/10.2307/258557

El Bizri, H. R., T. Q. Morcatty, J. J. S. Lima, and J. Valsecchi. 2015. The thrill of the chase: uncovering illegal sport hunting in Brazil through YouTube ${ }^{\mathrm{TM}}$ posts. Ecology and Society 20(3):30. http://dx.doi.org/10.5751/ES-07882-200330

European Food Safety Authority (EFSA). 2014. Evaluation of possible mitigation measures to prevent introduction and spread of African swine fever virus through wild boar. EFSA Journal 12 (3):3616. http://dx.doi.org/10.2903/j.efsa.2014.3616

Fernández, N., S. Kramer-Schadt, and H.-H. Thulke. 2006. Viability and risk assessment in species restoration: planning reintroductions for the wild boar, a potential disease reservoir. Ecology and Society 11(1):6. http://dx.doi.org/10.5751/ES-01560-110106 
Foster, C. N., P. S. Barton, and D. B. Lindenmayer. 2014. Effects of large native herbivores on other animals. Journal of Applied Ecology 51(4):929-938. http://dx.doi.org/10.1111/1365-2664.12268

Frackowiak, W., S. Gorczyca, D. Merta, and M. WojciuchPloskonka. 2013. Factors affecting the level of damage by wild boar in farmland in north-eastern Poland. Pest Management Science 69(3):362-366. https://doi.org/10.1002/ps.3368

Gavin, M. C., J. N. Solomon, and S. G. Blank. 2010. Measuring and monitoring illegal use of natural resources. Conservation Biology 24(1):89-100. http://dx.doi.org/10.1111/j.1523-1739.2009.01387. $\underline{\mathrm{x}}$

Geisser, H., and H.-U. Reyer. 2004. Efficacy of hunting, feeding, and fencing to reduce crop damage by wild boars. Journal of Wildlife Management 68(4):939-946. http://dx.doi.org/10.2193/0022-541X (2004)068[0939:EOHFAF]2.0.CO;2

Geisser, H., and H.-U. Reyer. 2005. The influence of food and temperature on population density of wild boar Sus scrofa in the Thurgau (Switzerland). Journal of Zoology 267(1):89-96. http:// dx.doi.org/10.1017/S095283690500734X

Gibbert, M., M. Hoegl, and L. Välikangas. 2007. In praise of resource constraints. MIT Sloan Management Review 48 (3):15-17. [online] URL: https://sloanreview.mit.edu/article/inpraise-of-resource-constraints/

Gibbert, M., M. Hoegl, and L. Valikangas. 2014. Introduction to the special issue: Financial resource constraints and innovation. Journal of Product Innovation Management 31(2) 197-201. https:// doi.org/10.1111/jpim.12089

Gibbert, M., W. Ruigrok, and B. Wicki. 2008. What passes as a rigorous case study? Strategic Management Journal 29 (13):1465-1474. https://doi.org/10.1002/smj.722

Gunderson, L., and S. S. Light. 2006. Adaptive management and adaptive governance in the everglades ecosystem. Policy Sciences 39(4):323-334. http://dx.doi.org/10.1007/s11077-006-9027-2

Hare, D., and B. Blossey. 2014. Principles of public trust thinking. Human Dimensions of Wildlife 19(5):397-406. http://dx.doi. org/10.1080/10871209.2014.942759

Hayward, M. W., L. Boitani, N. D. Burrows, P. J. Funston, K. U. Karanth, D. I. MacKenzie, K. H. Pollock, and R. W. Yarnell. 2015. Ecologists need robust survey designs, sampling and analytical methods. Journal of Applied Ecology 52(2):286-290. https://doi.org/10.1111/1365-2664.12408

Hearn, R., C. Watkins, and R. Balzaretti. 2014. The cultural and land use implications of the reappearance of the wild boar in North West Italy: a case study of the Val di Vara. Journal of Rural Studies 36:52-63. http://dx.doi.org/10.1016/j.jrurstud.2014.06.004

Keuling, O., E. Baubet, A. Duscher, C. Ebert, C., Fischer, A. Monaco, T. Podgórski, C. Prevot, K. Ronnenberg, G. Sodeikat, N. Stier, and H. Thurfjell. 2013. Mortality rates of wild boar Sus scrofa L. in central Europe. European Journal of Wildlife Research 59(6):805-814. https://doi.org/10.1007/s10344-013-0733-8

La Stampa. 2018. Polizia provinciale del Vco ancora senza mezzi: stop anche al contenimento dei cinghiali. La Stampa 25 July 2018. [online] URL: http://www.lastampa.it/2018/07/25/verbania/polizia- provinciale-del-vco-ancora-senza-mezzi-stop-anche-al-contenimentodei-cinghiali-B5q4qauomZkAfqn1y0bxCN/pagina.html

Lab, S. P. 2014. Crime prevention: approaches, practices, and evaluations. Eighth edition. Elsevier, Waltham, Massachusetts, USA.

Legard, R., J. Keegan, and K. Ward. 2003. In-depth interviews. Pages 138-169 in J. Ritchie and J. Lewis, editors. Qualitative research practice: a guide for social science students and researchers. Sage, London, UK.

Lieberman, E. S. 2005. Nested analysis as a mixed-method strategy for comparative research. American Political Science Review 99(3):435-452. http://dx.doi.org/10.1017/S0003055405051762

Linkie, M., S. Sloan, R. Kasia, D. Kiswayadi, and W. Azmi. 2014. Breaking the vicious circle of illegal logging in Indonesia. Conservation Biology 28(4):1023-1033. https://doi.org/10.1111/ cobi. 12255

Massei, G., J. Kindberg, A. Licoppe, D. Gačić, N. Šprem, J. Kamler, E. Baubet, U. Hohmann, A. Monaco, J. Ozolinš, S. Cellina, T. Podgórski, C. Fonseca, N. Markov, B. Pokorny, C. Rosell, an A. Náhlik. 2015. Wild boar populations up, numbers of hunters down? A review of trends and implications for Europe. Pest Management Science 71(4):492-500. https://doi.org/10.1002/ ps.3965

Massei, G., S. Roy, and R. Bunting. 2011. Too many hogs? A review of methods to mitigate impact by wild boar and feral hogs. Human-Wildlife Interactions 5(1):10. [online] URL: https:// digitalcommons.usu.edu/hwi/vol5/iss1/10

Mateo-Tomás, P., P. P. Olea, I. S. Sánchez-Barbudo, and R. Mateo. 2012. Alleviating human-wildlife conflicts: identifying the causes and mapping the risk of illegal poisoning of wild fauna. Journal of Applied Ecology 49(2):376-385. https://doi.org/10.1111/ j.1365-2664.2012.02119.x

Nurse, A. 2016. Animal harm: perspectives on why people harm and kill animals. Routledge, London, UK.

O'Reilly, K. 2012. Ethnographic methods. Second edition. Routledge, London, UK.

Olsson, P., L. H. Gunderson, S. R. Carpenter, P. Ryan, L. Lebel, C. Folke, and C. S. Holling. 2006. Shooting the rapids: navigating transitions to adaptive governance of social-ecological systems. Ecology and Society 11(1):18. http://dx.doi.org/10.5751/ ES-01595-110118

Plumptre, A. J., R. A. Fuller, A. Rwetsiba, F. Wanyama, D. Kujirakwinja, M. Driciru, G. Nangendo, J. E. M. Watson, and H. P. Possingham. 2014. Efficiently targeting resources to deter illegal activities in protected areas. Journal of Applied Ecology 51 (3):714-725. http://dx.doi.org/10.1111/1365-2664.12227

Pohja-Mykrä, M. 2016. Felony or act of justice? - Illegal killing of large carnivores as defiance of authorities. Journal of Rural Studies 44:46-54. http://dx.doi.org/10.1016/j.jrurstud.2016.01.003

Regione Piemonte. 2008. Studio delle caratteristiche genetiche delle popolazioni di cinghiale presenti in Piemonte. Laboratorio Chimico, Camera Di Commercio Torino and Università degli Studi di Sassari, Turin, Italy. [online] URL: http://www.regione. 
piemonte.it/agri/area_tecnico_scientifica/osserv_faun/dwd/prog_ricerca/ cinghiale.pdf

Regione Piemonte. 2013. Piano faunistico-venatorio regionale. Regione Piemonte, Turin, Italy. [online] URL: http://www. regione.piemonte.it/governo/bollettino/abbonati/2013/38/attach/ dgr 06368040 17092013.pdf

Scandura, M., L. Iacolina, and M. Apollonio. 2011. Genetic diversity in the European wild boar Sus scrofa: phylogeography, population structure and wild $\mathrm{x}$ domestic hybridization. Mammal Review 41(2):125-137. https://doi.org/10.1111/j.1365-2907.2010.00182. $\underline{\mathrm{x}}$

Schley, L., M. Dufrêne, A. Krier, and A. C. Frantz. 2008. Patterns of crop damage by wild boar (Sus scrofa) in Luxembourg over a 10-year period. European Journal of Wildlife Research 54:589-599. https://doi.org/10.1007/s10344-008-0183-x

Schley, L., and T. J. Roper. 2003. Diet of wild boar Sus scrofa in Western Europe, with particular reference to consumption of agricultural crops. Mammal Review 33(1):43-56. http://dx.doi. org/10.1046/j.1365-2907.2003.00010.x

Servanty, S., J.-M. Gaillard, F. Ronchi, S. Focardi, E. Baubet, and O. Gimenez. 2011. Influence of harvesting pressure on demographic tactics: implications for wildlife management. Journal of Applied Ecology 48(4):835-843. https://doi. org/10.1111/j.1365-2664.2011.02017.x

Servanty, S., J.-M. Gaillard, C. Toïgo, S. Brandt, and E. Baubet. 2009. Pulsed resources and climate-induced variation in the reproductive traits of wild boar under high hunting pressure. Journal of Animal Ecology 78(6):1278-1290. https://doi. org/10.1111/j.1365-2656.2009.01579.X

Snow, N. P., M. A. Jarzyna, and K. C. VerCauteren. 2017. Interpreting and predicting the spread of invasive wild pigs. Journal of Applied Ecology 54(6):2022-2032. http://dx.doi. org/10.1111/1365-2664.12866

Spencer, P. B. S., and J. O. Hampton. 2005. Illegal translocation and genetic structure of feral pigs in Western Australia. Journal of Wildlife Management 69(1):377-384. http://dx.doi. org/10.2193/0022-541X(2005)069<0377:ITAGSO>2.0.CO:2

Stillfried, M., J. Fickel, K. Börner, U. Wittstatt, M. Heddergott, S. Ortmann, S. Kramer-Schadt, and A. C. Frantz. 2017. Do cities represent sources, sinks or isolated islands for urban wild boar population structure? Journal of Applied Ecology 54(1):272-281. https://doi.org/10.1111/1365-2664.12756

Toïgo, C., S. Servanty, J.-M. Gaillard, S. Brandt, and E. Baubet. 2008. Disentangling natural from hunting mortality in an intensively hunted wild boar population. Journal of Wildlife Management 72(7):1532-1539. https://doi.org/10.2193/2007-378

Treves, A., R. L. Jurewicz, L. Naughton-Treves, and D. S. Wilcove. 2009. The price of tolerance: wolf damage payments after recovery. Biodiversity and Conservation 18(14):4003-4021. http:// dx.doi.org/10.1007/s10531-009-9695-2

Viganò, R., A. Cottini, and F. Fili. 2017. Filiera eco-alimentare: la valorizzazione delle carni di selvaggina: la gestione di prodotto sostenibile come strumento di stimolo al miglioramento ambientale dei territori alpini. Associazione ARS.UNI.VCO, Domodossola,
Italy. [online] URL: http://www.univco.it/uploads/Fondazione $\%$ 20CARIPLO/E-book_filiera.pdf

Yasuoka, H., M. Hirai, T. O. W. Kamgaing, Z. C. B. Dzefack, E. C. B. Kamdoum, and K. S. Bobo. 2015. Changes in the composition of hunting catches in southeastern Cameroon: a promising approach for collaborative wildlife management between ecologists and local hunters. Ecology and Society 20 (4):25. http://dx.doi.org/10.5751/ES-08041-200425

Yin, R. K. 2008. Case study research: design and methods. Fourth edition. Sage, Thousand Oaks, California, USA. 